\title{
Expressed sequence-tag analysis of ovaries of Brachiaria brizantha reveals genes associated with the early steps of embryo sac differentiation of apomictic plants
}

\author{
Érica Duarte Silveira - Larissa Arrais Guimarães - Diva Maria de Alencar Dusi • \\ Felipe Rodrigues da Silva • Natália Florencio Martins $\cdot$ Marcos Mota do Carmo Costa • \\ Márcio Alves-Ferreira $\cdot$ Vera Tavares de Campos Carneiro
}

Received: 4 August 2011/Revised: 10 October 2011/Accepted: 12 October 2011/Published online: 9 November 2011

(C) Springer-Verlag 2011

\begin{abstract}
In apomixis, asexual mode of plant reproduction through seeds, an unreduced megagametophyte is formed due to circumvented or altered meiosis. The embryo develops autonomously from the unreduced egg cell, independently of fertilization. Brachiaria is a genus of tropical forage grasses that reproduces sexually or by apomixis. A limited number of studies have reported the sequencing of apomixis-related genes and a few Brachiaria sequences have been deposited at genebank databases. This work shows sequencing and expression analyses of
\end{abstract}

Communicated by K. Wang.

Electronic supplementary material The online version of this article (doi:10.1007/s00299-011-1175-y) contains supplementary material, which is available to authorized users.

É. D. Silveira - L. A. Guimarães · D. M. de Alencar Dusi ·

F. R. da Silva · N. F. Martins - M. M. do Carmo Costa .

V. T. de Campos Carneiro $(\square)$

Embrapa Genetic Resources and Biotechnology,

Parque Estação Biológica, PqEB, Av. W5 Norte (final) Caixa

Postal 02372, 70770917 Brasília DF, Brazil

e-mail: vera@cenargen.embrapa.br

\section{É. D. Silveira - M. Alves-Ferreira}

Department of Genetics, Federal University of Rio de Janeiro, Av. Prof. Rodolpho Paulo Rocco, s/n Prédio do CCS Instituto de Biologia, 2 andar, 21941-970 Rio de Janeiro, RJ, Brazil

Present Address:

É. D. Silveira

Facultad de Ciencias Agrarias, Universidad Catolica Argentina, Cap. Gral. Ramón Freire 183, Ciudad Autónoma de Buenos

Aires, Buenos Aires, Argentina

L. A. Guimarães

Department of Cell Biology, University of Brasília,

UnB, Campus Universitário Darcy Ribeiro, S/N-Asa Norte,

70919- 970 Brasília DF, Brazil expressed sequence-tags (ESTs) of Brachiaria genus and points to transcripts from ovaries with preferential expression at megasporogenesis in apomictic plants. From the 11 differentially expressed sequences from immature ovaries of sexual and apomictic Brachiaria brizantha obtained from macroarray analysis, 9 were preferentially detected in ovaries of apomicts, as confirmed by RT-qPCR. A putative involvement in early steps of Panicum-type embryo sac differentiation of four sequences from $B$. brizantha ovaries: BbrizHelic, BbrizRan, BbrizSec13 and BbrizStil is suggested. Two of these, BbrizStil and BbrizHelic, with similarity to a gene coding to stress induced protein and a helicase, respectively, are preferentially expressed in the early stages of apomictic ovaries development, especially in the nucellus, in a stage previous to the differentiation of aposporous initials, as verified by in situ hybridization.

Keywords Apomixis - EST - Forage grass - Ovaries · Plant reproduction

\section{Introduction}

In angiosperms, sexual reproduction begins with the formation of sexual spores via meiosis, producing microspores and megaspores, a phenomenon called sporogenesis. At gametogenesis, through successive mitoses, multicellular gametophytes are formed: in the anther, the microgametophyte or pollen grain, and in the ovule, the megagametophyte or embryo sac. The pollen grain contains one vegetative cell and two sperm cells, all haploids (n). The embryo sac contains seven cells: three antipodals, two synergids and one egg cell, haploids, and a diploid (2n) central cell. Double fertilization occurs in the ovule when one sperm cell fertilizes the egg cell and the other sperm cell fertilizes the central cell 
giving rise, respectively, to the diploid zygote, the precursor of the embryo, and the triploid endosperm. Together with the surrounding maternal sporophytic tissue, they form the seed.

Among the asexual modes of plant reproduction, gametophytic apomixis comprises the autonomous development of embryos from an unreduced gamete. Gametophytic apomixis differs from sexual reproduction by formation of an unreduced embryo sac due to circumvented or altered meiosis during megasporogenesis (apomeiosis), and by embryo development without fertilization of the egg cell (Nogler 1984). The unreduced embryo sac can be originated from nucellar cells, in apospory, or from the megaspore mother cell, in diplospory (Nogler 1984).

Brachiaria is the most widely cultivated and economically important forage grass in Brazil (Araújo et al. 2008) which is the largest meat exporter country (CREMAQ 2010) and has most of its cattle herd raised under pasture conditions. Reproduction in Brachiaria is mainly by aposporic apomixis (Miles et al. 1996).

Apomixis is an agronomically desirable trait for modern agriculture, since it can be used to fix relevant multigenic characteristics in important crops. The financial benefit from cloning hybrids through apomixis, in rice only, was estimated at 2.5 billion US dollars per year (McMeniman and Lubulwa in Spillane et al. 2004). In contrast, switching apomixis to sexuality in Brachiaria is desirable for breeding programs, considering that it would contribute to increasing the genetic variability of this forage grass by allowing the use of hybridization techniques to generate new varieties. However, apomixis is still poorly understood, hindering efforts to develop apomictic cultivars in crops, such as maize, rice and wheat and to manipulate apomixis and sexuality in Brachiaria (Pinheiro et al. 2000; Araujo et al. 2005).

In aposporic Brachiaria decumbens and Brachiaria brizantha, a somatic cell of the nucellus, the aposporous initial (ai), after two successive mitoses, gives rise to an unreduced Panicum-type embryo sac, containing four cells: two synergids, one egg cell and a central cell, all 2n (Dusi and Willemse 1999; Araujo et al. 2000). Only the fertilization of the central cell is required to form the seed (Ngendahayo 1988; Alves et al. 2001). Autonomous embryo development occurs from the unreduced egg cell, generating identical progeny from maternal origin. Deregulation of genes associated with megasporogenesis could redirect the gametophyte development pathway towards apomixis. One evidence that supports this idea is that characteristics of ovary and embryo formation of apomicts were found in mutated sexual plants (Grossniklaus 2001; Tucker et al. 2003) and associations between important genes related to seed development and apomixis were made in Arabidopsis thaliana mutants (Ohad et al. 1996; Chaudurhy et al. 1997). An important process analogous to the first steps of diplospory was described in the A. thaliana dyad mutant where the megaspore mother cell forms an embryo sac without reduction by meiosis, apomeiosis (Ravi et al. 2008). Also in A. thaliana, a triple mutant genotype called MiMe had meiosis replaced by mitosis, forming an unreduced embryo sac, similarly to diplospory (d'Erfurth et al. 2009). Clonal reproduction through seeds, achieved by crossing mutants that form unreduced embryo sacs, MiMe and dyad, with a strain that eliminate chromosomes after fertilization (Marimuthu et al. 2011), raised expectations for engineering apomixis in important crops. In a process more similar to apospory, it was reported that ago 9 mutants (mutation on gene ARGONAUTE 9) differentiated into multiple cells in the nucellus, being able to initiate gametogenesis (OlmedoMonfil et al. 2010). Recently, Singh et al. (2011) demonstrated that a maize mutant on a gene orthologous of the Arabidopsis AGO9 (AGO 104) is defective in chromatin condensation during meiosis and produces unreduced viable megagametophytes.

Apomictic plants have common developmental characteristics (Ozias-Akins 2006) and the identification of megagametophyte related genes of apomicts can contribute to discover the gene expression programs involved in the regulation of this mode of reproduction. In apomictic plants, the main steps and the genes involved in the formation of megagametophytes are still poorly understood. Only a limited number of studies have been carried out on ESTs analysis of apomictic species, such as Poa pratensis (Albertini et al. 2004), Eragrostis curvula (Cervigni et al. 2008), Panicum maximum (Yamada-Akiyama et al. 2009), Paspalum simplex (Polegri et al. 2010) and Boechera spp. (Sharbel et al. 2010).

In $B$. brizantha, our group identified 11 ESTs, ten of them differentially expressed in ovaries of the apomictic BRA 000591, cv. Marandu, and the sexual BRA 002747 accessions (Rodrigues et al. 2003). Among these sequences, specificity to megasporogenesis and megagametogenesis was detected. Three of them were expressed mostly in synergids at late stages of embryo sac development; $B b r i z M Y O$, in apomictic and sexual plants, and BbrizAQP and $B b r i z M A P K$, in apomictic plants. Their involvement in autonomous embryo development, a characteristic of apomicts, was suggested (Alves et al. 2007).

In this work, ESTs of ovaries before anthesis of sexual and apomictic B. brizantha were sequenced and annotated. For a more detailed insight into gene expression in the female development of $B$. brizantha, we examined gene expression patterns of 166 ESTs in immature ovaries, comparing sexual and apomictic $B$. brizantha using macroarray, Rt-qPCR and in situ hybridization. The putative role of the differential sequences during apomixis development in $B$. brizantha is discussed. 


\section{Materials and methods}

Plant material

Two accessions of $B$. brizantha (Syn. Urochloa brizantha) from Embrapa's germplasm collection were used in this work: BRA 002747 (B105), a sexual diploid $(2 \mathrm{n}=$ $2 x=18$ ), and BRA 000591 (B030), a facultative apomictic tetraploid $(2 \mathrm{n}=4 x=36)$ named $B$. brizantha cv. Marandu, with up to $98 \%$ of apospory (Araujo et al. 2000). Both were cultivated in the field at Embrapa Genetic Resources and Biotechnology (Brasília-DF, Brazil).

\section{RNA extraction and EST library construction}

Four different EST libraries were constructed, two from ovaries of the sexual and two from ovaries of the apomictic $B$. brizantha at two different developmental stages: megasporogenesis and late megagametogenesis, as previously categorized (Araujo et al. 2000). Megasporogenesis includes stages I and II of ovary development, from megaspore mother cells to functional megaspore differentiation in sexuals and, in apomicts, it comprises differentiation of ai and degeneration of the tetrad. In late megagametogenesis, at stage IV, before anthesis, the embryo sacs are cellularized.

For each cDNA library, 70-90 $\mu \mathrm{g}$ of total RNA was extracted with TRIZOL $\AA$ (Invitrogen ${ }^{\mathrm{TM}}$ ) according to Rodrigues et al. (2003). Poly (A) ${ }^{+}$RNA was purified using Dynabeads $\left(\right.$ Dynal $^{\circledR}$ ), according to the manufacturer's protocol. Samples were diluted in $2 \mu$ of DEPC-treated water and the first strand cDNA synthesis was conducted.

The four directional cDNA libraries were constructed using the Creator SMART cDNA Library Construction Kit (Clontech), according to the User Manual, in pTriplex2 vector. After insert ligation into pTriplex2 vectors, the resulting plasmids were transformed by electroporation in Escherichia coli Xl1Blue strain. The white colonies grown on LB/Xgal/IPTG solid media were picked at random for sequencing. The libraries were named as follows: B030_IeII, of ovaries of apomictic plants at megasporogenesis; B030_-IV-, of ovaries of apomictic plants with mature embryo sacs; B105_IeII, of ovaries of sexual plants at megasporogenesis; B105_-IV-, of ovaries of sexual plants with mature embryo sacs.

\section{EST library sequencing and analysis}

After plasmid DNA isolation of inserts, the 2,976 purified plasmids were sequenced using the oligonucleotides: PT2 F2 (5'GCGCCATTGTGTTGGTACCC $\left.3^{\prime}\right)$ and PT2R2 (5' CCGCATGCATAAGCTTGCTC 3' (Proite et al. 2007), respectively, and the Dye Terminator chemistry, on automated sequencers ABI 377 and ABI 3700 (Applied
Biosystems) at Embrapa Genetics Resources and Biotechnology's DNA sequencing platform. The first clones obtained, used for validation of libraries (768 EST) were sequenced with $5^{\prime}$ and $3^{\prime}$ end primers. The other 2,208 were sequenced with the $3^{\prime}$ end primer only. Base calling and quality analysis of individual bases of the ESTs were performed using the program PHRED (Ewing et al. 1998). For insert size determination, 192 clones were picked and, after PCR reaction using PT2F2 and PT2R2, analyzed by electrophoresis in $1 \%$ agarose gel.

Sequence analysis and annotation

Sequence trimming was done as described by Telles and Silva (2001), which resulted in removal of low-quality sequences, $\operatorname{Poly}(\mathrm{A})^{+}$RNA tails, ribosomal RNA, vector and primer regions. The sequences from the four libraries were then assembled into clusters using the CAP3 assembler (Huang and Madan 1998) to form unigenes. Sequence comparison using BLAST (Basic local alignment search tool; Altschul et al. 1997) was performed locally. The cutoff $e$-value of $<e^{-5}$ was used to define the similar homologues and the unigene sets that did not meet this requirement were annotated as unknown. The following databases were used in the annotation step: GenBank nr (Benson et al. 2008), MIPS A. thaliana (Schoof et al. 2004) and SwissProt (Gasteiger et al. 2001). Predicted protein sequences were aligned with BLASTx against KOG-Eukaryotic Orthologous Groups (Tatusov et al. 2003) and Gene Ontology (Ashburner et al. 2000). The output was parsed by locally developed PERL scripts where the EST assembly and the result of several alignments were available for manual curation. Results from BLAST against five databases were used in the manual curation for all the unigenes: these were NR, MIPS, KOG and SwissProt. In addition, other sequences that have already been described in the literature as related to plant reproduction development were used to align against the sequences from this work in order to find Brachiaria sequences that can be related to reproductive development.

\section{Comparative analysis}

For comparison of Brachiaria ESTs to rice pistil ESTs available in the genebank, a Digital Differential Display was performed by forming clusters for these two EST groups with TGILC (Pertea et al. 2003). This software uses the following parameters for the cluster assembly: $40 \mathrm{bp}$ overlap, minimum of $95 \%$ of ID, maximum of $30 \mathrm{bp}$ of mismatch. The clusters are executed using CAP3 (Huang and Madan 1998) for generation of consensus sequences. A second round of clustering and trimming was performed according to Pappas et al. (2008). In this step, clustering of 2,634 reads were submitted to a pre-processing pipeline 
that starts with the base calling program PHRED (Ewing et al. 1998) followed by cloning vector removal with cross match (http://www.phrap.org), repeat masking with Repeat Masker (http://www.repeatmasker.org) and quality trimming with Lucy (Chu and Holmes 2001). The assembled ESTs were compared to Brachypodium distachyon ESTs (http://www.modelcrop.org/) and Sorghum bicolor gene models (http://genome.jgi-psf.org/Sorbi1/Sorbi1.home.html) by Bidirectional Best Hit according to Hulsen et al. (2006).

\section{Macroarray preparation and analysis}

To select the sequences to be blotted on to the membrane for hybridization, 166 ESTs were chosen mostly for their similarity to sequences already related to important processes of gamete differentiation. BLASTX and BLASTN results and analysis of their orthologous expression in The Arabidopsis Information Resource (TAIR, http://www. arabidopsis.org) were used. The sequences are listed in Supplementary Table 1 . The clones were obtained from the cDNA libraries, except for clone 21 (Rodrigues et al. 2003). Three clones were chosen as controls: clone 21 , actin and tubulin. These sequences were PCR-amplified using the same oligonucleotides used for sequencing the libraries, and blotted in duplicate onto Hybond $\mathrm{N}^{+}$membranes (Amersham Biosciences).

Four probes were prepared from $1 \mu \mathrm{g}$ of Poly (A) ${ }^{+}$RNA from leaves and immature ovaries of both sexual and apomictic $B$. brizantha. Total RNA and Poly $(\mathrm{A})^{+}$RNA were prepared as described for cDNA library construction, and probes were prepared according to Hotscribe firststrand cDNA labeling kit protocol (Amersham ${ }^{\mathrm{TM}}$ ).

\section{Hybridization}

The hybridization protocol and data analysis were previously established by Valle and Carvalho (personal communication). Membranes were pre-hybridized in $5 \times$ SSPE solution $\left(20 \times \mathrm{SSPE}=3 \mathrm{M} \mathrm{NaCl} ; 200 \mathrm{mM} \mathrm{NaH}_{2} \mathrm{PO}_{4} ; 20 \mathrm{mM}\right.$ $\mathrm{Na}_{2}$.EDTA. $2 \mathrm{H}_{2} 0, \mathrm{pH}$ 7.4); $5 \times$ Denhardt's solution; $0.5 \%$ SDS, for $2 \mathrm{~h}$, at $65^{\circ} \mathrm{C}$. Hybridization was performed with the same solution, except for the addition of the probes. Membranes were hybridized for $16 \mathrm{~h}$, at $65^{\circ} \mathrm{C}$ and washed in $2 \times$ SSPE solution $/ 0.1 \%$ SDS and $1 \mathrm{X}$ SSPE/ SDS $0.1 \%$, for 30 min each, at $65^{\circ} \mathrm{C}$. Membranes were then exposed to high sensitivity films and then scanned for image analysis.

Image and statistical analysis

The images were obtained using Agfa DuoScan T1200, generating high-resolution images. Signal intensity was quantified using Zero-Dscan version1 (Scanalytics
Division of CSPI, MA, USA), according to the manufacturer's instructions. Data were exported to MS Excel (Microsoft, Redmond, WA, USA), for statistical analysis, which was done according to Nogueira et al. (2003).

\section{RT-qPCR}

Oligonucleotides pairs were designed using Primer 3.0 program (Melting temperatures, Tm, varying between 59 and $60^{\circ} \mathrm{C}$ and primer lengths of $20-23 \mathrm{bp}$ ) for the 11 sequences with differential expression, detected by macroarray analysis (Supplementary Table 2). For RT-qPCR reaction, RNA was extracted from young leaves; from a pool of ovaries at the four stages before anthesis (I, II, III and IV) and from a pool of anthers at the corresponding stages of sexual and apomictic $B$. brizantha and 30 cycles were performed for each sample according to Silveira et al. (2009). PCR reactions were performed in 96-well plates with the Chromo4 Real-Time PCR Detector System (Bio$\operatorname{Rad}^{\circledR}$ ) using SYBR ${ }^{\circledR}$ Green to detect dsDNA synthesis. Reactions were done in $20 \mu \mathrm{L}$ volumes containing PCR Buffer (Invitrogen ${ }^{\mathrm{TM}}$ ), $1.5 \mathrm{mM} \mathrm{MgCl}, 0.1 \mathrm{mM}$ dNTPs, $0.25 \mathrm{U}$ Taq Platinum (Invitrogen ${ }^{\mathrm{TM}}$ ), 0.1X SYBR Green $\left(\right.$ Amersham $^{\mathrm{TM}}$ ), $200 \mathrm{nM}$ of each primer and $10 \mu \mathrm{sscDNA}$ (corresponding to $5 \mathrm{ng}$ of total RNA). Reactions were run in a BioRad RT-qPCR device using the following cycling parameters: $94^{\circ} \mathrm{C}$ for $5 \mathrm{~min}, 40$ cycles of $94^{\circ} \mathrm{C}$ for $15 \mathrm{~s}$, $60^{\circ} \mathrm{C}$ for $10 \mathrm{~s}, 72^{\circ} \mathrm{C}$ for $15 \mathrm{~s}$ and $60^{\circ} \mathrm{C}$ for $35 \mathrm{~s}$. No-template controls (NTC) were included for each primer pair, and each PCR reaction was performed in triplicate. Dissociation curves for each amplicon and agarose gel were then analyzed to verify the specificity of each amplification reaction; the dissociation curve was obtained by heating the amplicon from 40 to $100^{\circ} \mathrm{C}$ and reading at each ${ }^{\circ} \mathrm{C}$. Two biological replicates for each of the samples were used for RTqPCR analysis, and three technical replicates were analyzed for each biological replicate. Relative gene expression was calculated using qBase software version 1.3.4 (http:// medgen.ugent.be/qbase/). The reference gene used was BbrizUBI, previously described as the best reference gene for these samples in B. brizantha (Silveira et al. 2009). Also, for four sequences, to which the expression ratio between apomictic versus sexual ovaries was 2.5 times higher, RT-qPCR was performed using cDNAs synthesized from RNA extracted from ovaries at developmental stages I, II (megasporogenesis) and IV (mature embryo sac) (Araujo et al. 2000) for both sexual and apomictic B. brizantha, according to Silveira et al. (2009).

\section{$5^{\prime}$ Rapid amplification of cDNA ends (RACE)}

A Marathon ${ }^{\mathrm{TM}}$ cDNA library from ovaries of $B$. brizantha (Alves et al. 2007) was used for 5'-RACE experiments. 
Two specific oligonucleotides were designed for BbrizStil and BbrizHelic in a first round of RACE reaction. A second round was done for BbrizStil with two new specific oligonucleotides that anchored to elongate the $5^{\prime}$ region of these sequences. Specific oligonucleotides used are listed on Supplementary Table 3. The PCR cycle condition was: $94^{\circ} \mathrm{C}, 1 \mathrm{~min} ; 5$ cycles of $94^{\circ} \mathrm{C}, 30 \mathrm{~s}$ and $72^{\circ} \mathrm{C}, 4 \mathrm{~min} ; 5$ cycles of $94^{\circ} \mathrm{C}, 30 \mathrm{~s}$ and $70^{\circ} \mathrm{C}, 4 \mathrm{~min}$ and lastly 35 cycles of $94^{\circ} \mathrm{C}, 20 \mathrm{~s}$ and $68^{\circ} \mathrm{C} 4 \mathrm{~min}$. E. coli was transformed with pGEM vector (Promega) containing the PCR products, and plasmid DNA containing insert was purified (Sambrook et al. 1989) and sequenced. The sequences obtained were analyzed and contigs were formed using phred, phrap and CAP3 programs.

In situ hybridization

In situ hybridization (ISH) was performed in sections of ovaries from the sexual and the apomictic accessions at all stages of female gametophyte development. Tissue preparation, embedding and in situ hybridization and post hybridization were carried out as previously described (Dusi 2001). The RNA probe was synthesized using the DIG RNA labeling kit (Roche) according to the manufacturer's protocol. PCR fragments of 150-300 bp from $3^{\prime}$ coding regions of BbrizStil and BbrizHelic were cloned into pGEM-T Easy Vector System I (Invitrogen ${ }^{\mathrm{TM}}$ life technologies) and used as a template for in vitro transcription with T7 and SP6 polymerases, used as sense and antisense probes, respectively. Sections were hybridized with $600 \mathrm{ng} / \mathrm{mL}$ DIG-labeled RNA probe, overnight, at either 42,55 or $60^{\circ} \mathrm{C}$. After washing and mounting, sections were observed with a Zeiss Axiophot light microscope. Before hybridization, a few samples were stained with acridine orange and examined under UV light for RNA integrity checking.

\section{Results}

Analysis of EST libraries

For bioinformatics analysis, the four EST libraries which were sequenced separately were gathered as a unique library of $B$. brizantha ovaries, containing ESTs from ovaries of the very early stage of development until ovaries before anthesis, with a bias for early-stage ovaries of apomictic plants. From a total of 2,976 clones sequenced, $2,198(73.9 \%)$ showed high quality after trimming and were analyzed for function prediction. The majority of high quality EST reads $(1,647)$ were derived from the library of ovaries of apomictic plants at megasporogenesis (B030_IeII), while 196 ESTs were from the library of ovaries containing mature embryo sacs of apomicts (B030_-IV-), 215 from the library of ovaries of sexual plants at megasporogenesis (B105_IeII) and 140 from ovaries of sexual plants with mature embryo sacs (B105_-IV-). These ESTs were assembled as 1,832 putative transcripts (contigs): 240 clusters and 1,592 singletons. The quality of the resultant combined libraries was confirmed by insert sizes. Of these, $28.6 \%$ corresponded to clones with inserts smaller than $500 \mathrm{bp}, 69.2 \%$ with inserts between $500 \mathrm{bp}$ and $1 \mathrm{~Kb}$, and $4 \%$ with inserts larger than $1 \mathrm{~kb}$. The most abundant ESTs contained six to 14 reads. The two contigs with the highest number of reads are similar to a hypothetical protein and a no-hit sequence. The encoded protein shows high similarity to hypothetical proteins of Medicago trunculata (gb|ABO81861.1I) and Oryza sativa (gb|DQ167400.1). Out of 1,236 contigs annotated, the majority $(71.6 \%)$ had no hits to well characterized proteins described in five public databases (NR database, MIPS database, KOG, Swiss-Prot and Pfam) and thus could not be classified into protein family groups. The remainder of the contigs $(28.4 \%)$ showed significant similarity to already described proteins and were divided into categories in relation to their predicted function in $\mathrm{KOG}$ (Fig. 1). According to the eukaryotic orthologous group database (KOG), 257 contigs encoded predicted hypothetical proteins. From the five main KOG groups, ESTs from ovaries of $B$. brizantha showed high similarity to proteins related to processes and signaling $(35.8 \%)$, as shown in Fig. 1. These groups include 25 functional categories (available in KOG), and these libraries have contigs distributed among 23 of them, ranging from 0.4 to $16.7 \%$ (Fig. 1).

An extensive search of sequences already described in the literature was performed in order to create a database of sequences related to reproductive development and to compare it to the sequences generated in this library. Among the annotated ESTs, some encoded proteins were similar to proteins known to be involved in sexual and apomictic megagametophyte development. Ortholog candidates of these sequences were selected in order to check their involvement either in sexual or apomictic development (Supplementary Table 1). Some B. brizantha contigs were similar to sequences related to plant reproductive development, especially in A. thaliana. Information available in the literature and, mostly, in The Arabidopsis Information Resource (TAIR; http://www.arabidopsis.org) were used to make this relation between Brachiaria sequences and their possible involvement in reproductive development.

Seven contigs showed similarity between 82 and $95 \%$ with MADS-Box genes from monocots using BLASTN and BLASTP. One of those contigs represented a fulllength coding sequence with $1,159 \mathrm{bp}$ and 384 deduced amino acids (B030_IeII001_G05; Supplementary Table 1). 


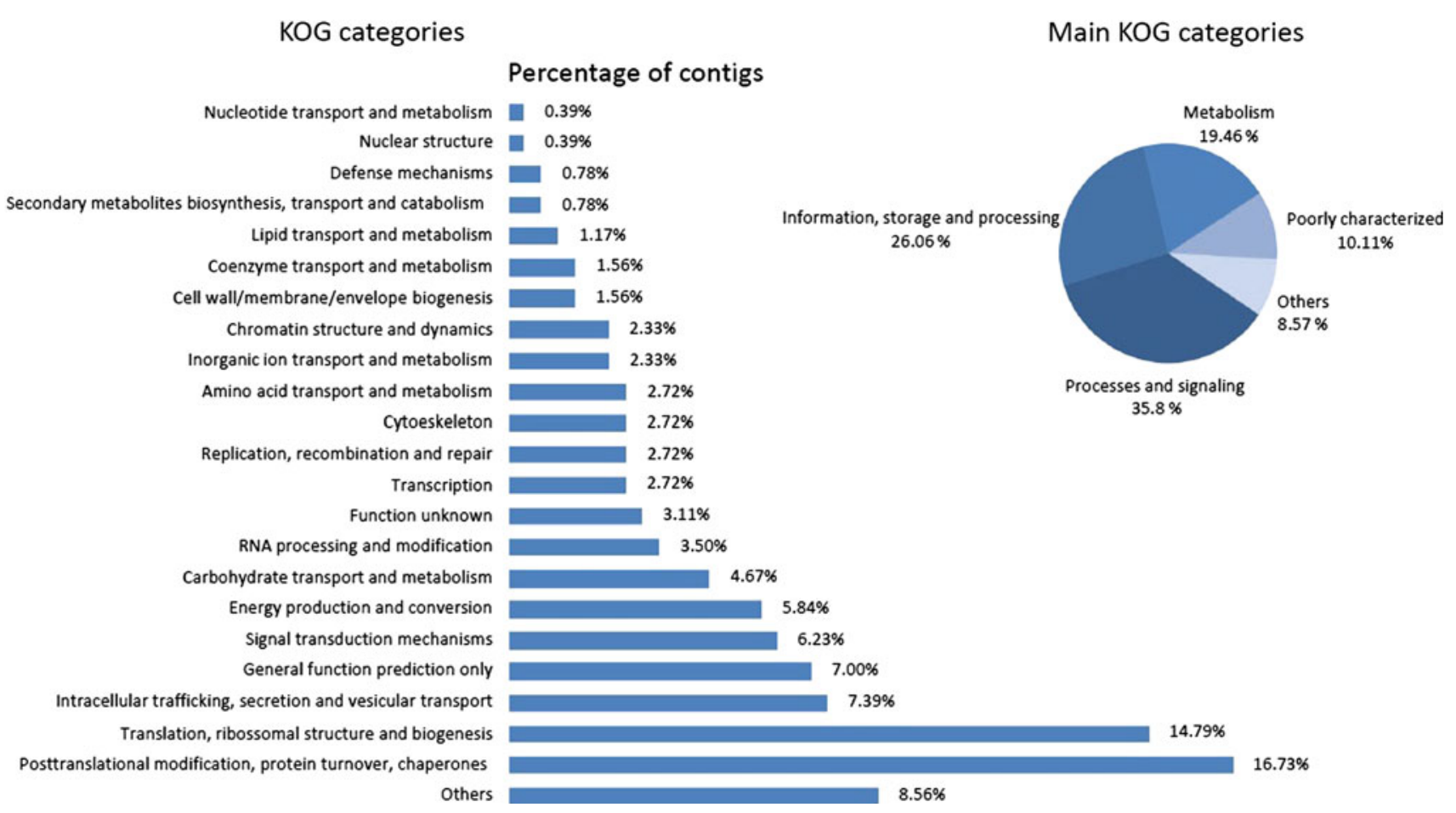

Fig. 1 Functional classification of the 257 annotated contigs among the main KOG categories and subcategories

This sequence showed similarity to the ZAG gene family (for Zea mays AGAMOUS), with 51/67 (76\%) identity, and whose functional analysis has not yet been described in the literature.

The EST data showed six contigs that have similarity to helicase proteins. One of them is similar to a SNF2/SWI2like protein of 768 bp sequence, which belongs to a chromatin remodeling family, showing an $e$-value of $2 e^{-9}$, and identity of $28 / 36(77 \%)$ to $O$. sativa Os02g0114000 gene (B030_IeII_033_C07). Also, a chromatin remodeling factor family member, of $582 \mathrm{bp}$, showed the best hit to the O. sativa Os04g0692700 and a CHR11 of Arabidopsis, with $e$-value of $9 e^{-09}$, and identity of 32/70 (45\%), (B030_IeII 007_C04; Supplementary Table 1). This gene is involved in haploid nuclear proliferation during megagametophyte development (Huanca-Mamani et al. 2005). Two contigs showed similarity to $S K P 1$-like genes and also an $A R G$ ONAUTE gene, both involved in meiosis. The SKP1 from $B$. brizantha showed its best hit to O. sativa (B030IeII010_ D05; Supplementary Table 1) and Medicago trunculata SKPl-like genes, with $e$-value of $3 e^{-09}$ and $1 e^{-11}$, and identity of $43 / 52(82 \%)$ and $34 / 46(73 \%)$, respectively. The sequences were from 712 and $673 \mathrm{bp}$. The putative Brachiaria ARGONAUTE gene, a 579 bp sequence, is more similar to Arabidopsis ARGONAUTE 4 and 9, with an $e$-value of $1 e^{-39}$ and identity of 77/102 (75\%) and 78/102 (76\%), respectively (B030_IeII007_H05; Supplementary Table 1).

Another gene previously characterized as important for meiosis regulation is the DMCl (disrupted meiotic cDNA), a highly conserved gene among all clades. The $B$. brizantha $D M C 1$ showed high similarity to $O s D M C 1$, its best hit on BlastX. It is an 858-bp sequence derived from the B030_IeII library of ovaries of apomicts at megasporogenesis, with an $e$-value of $5 e^{-99}$ and identity of $185 / 187$ (98\%) with OsDMC1 protein (B030_IeII002_B09; Supplementary Table 1).

In addition, ESTs of chromosomal modification and transcriptional regulation, hormone-associated genes and stress-related proteins were identified (Supplementary Table 1) and could be related to those already described as being involved in reproductive development in other species.

For the comparison with the Brachypodium and Sorghum gene models, that would enrich the annotation of Brachiaria sequences, 1,576 clusters (219 contigs and 1,357 singlets) were generated by a second round of clustering and trimming according to Pappas et al. (2008). Most $B$. brizantha sequences showed similarity with the genomes of $B$. distachyon and, mainly, of $S$. bicolor (Fig. 2), according to the TGICL software used for this comparison (Pertea et al. 2003).

Macroarray analysis

Among the 166 ESTs encoding proteins putatively involved in megagametophyte development (Supplementary Table 1), a macroarray analysis was performed to check their differential expression in ovaries of sexual and 


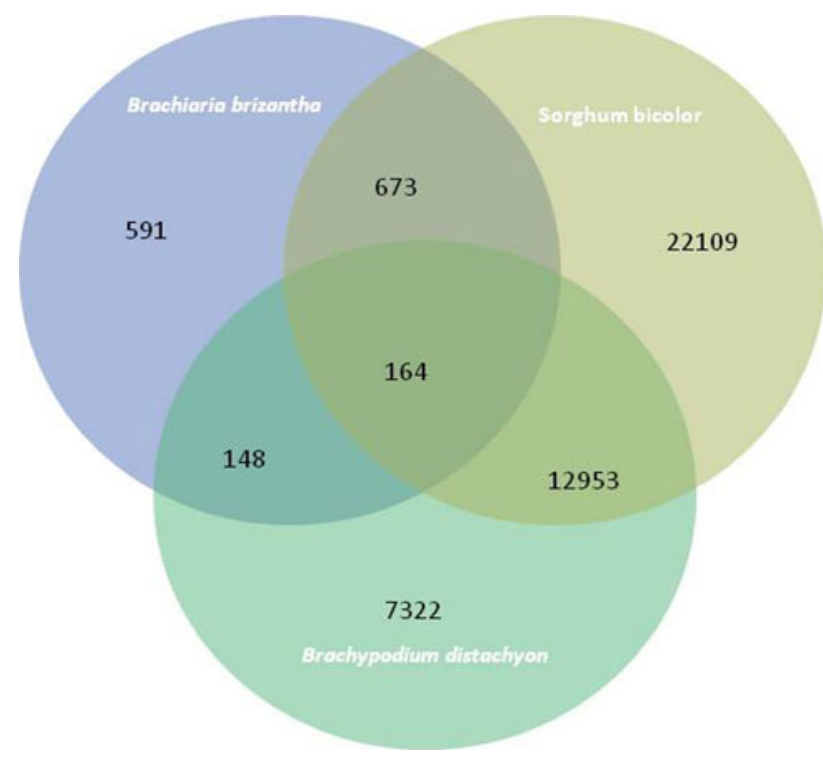

Fig. 2 Venn diagram showing the number of unique and shared genes amongst 1,576 ESTs from Brachiaria brizantha and ESTs from Brachypodium distachyon and Sorghum bicolor

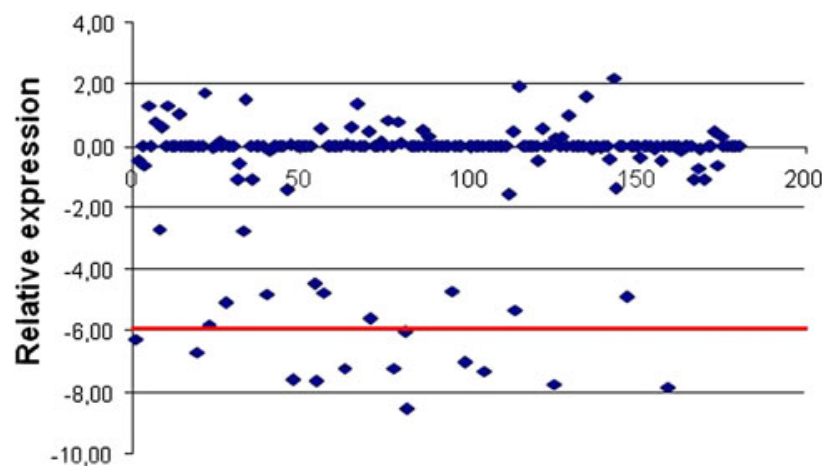

Fig. 3 EST dispersion graphic shows the relative expression in ovaries of sexual versus apomictic Brachiaria brizantha. Dots with relative expression under -6.00 correspond to the genes considered as differentially expressed

apomictic B. brizantha plants. Out of 103 ESTs (61.6\%) that fulfilled selection criteria for signal detection, 11 are differentially expressed in sexual and apomictic ovaries of B. brizantha (Fig. 3). For sake of simplicity, these ESTs are named according to their best hit on sequence databases (Table 1).

\section{RT-qPCR}

To validate macroarray data and to investigate the expression profile of the 11 ESTs differentially expressed in sexual and apomictic ovaries of $B$. brizantha, RT-qPCR experiments were performed using RNA isolated from the reproductive organs (anthers and ovaries) and leaves. Among them, nine ESTs had higher expression in ovaries of apomictic than in sexual plants (Fig. 4), as confirmed by RT-qPCR. For a rigorous comparison of RT-qPCR results, in a previous work, we have identified in B. brizantha the best reference genes in samples equivalent to those used here (Silveira et al. 2009). In apomictic plants, a higher expression in ovaries than in leaves was confirmed for all EST tested, with an exception to BbrizTom1.

Considering only the four sequences with more than 2.5 times difference on the expression in ovaries of apomicts than of sexual plants, BbrizHelic, BbrizRan, BbrizSec13 and BbrizStil, a more detailed expression analysis throughout different stages of ovary development was performed using RNA from ovaries at megasporogenesis (stages I and II) and at mature embryo sac stage (stage IV), of both sexual and apomictic B. brizantha (Fig. 5). The higher expression of the four ESTs in ovaries of apomicts than of sexual plants was confirmed (Fig. 5). Interestingly, all four tested sequences showed higher expression in the early stages of apomictic ovaries development, mainly stage II. Among them, BbrizStil and BbrizHelic were not expressed in ovaries of sexual plants, in any of the stages of development tested, suggesting involvement in cell development at the very early stages of apomictic differentiation and analyses of these sequences were continued.

\section{5' RACE and ISH for BbrizHelic and BbrizSti1}

BbrizHelic and BbrizStil were cloned from the EST library of apomictic $B$. brizantha ovaries at megasporogenesis (B030_IeII). BbrizStil consists of a 1,259 bp fragment encoding a 345 amino acid polypeptide with high similarity to STI1 (stress induced 1) proteins, such as STI1 of O. sativa, S. bicolor, Zea mays and A. thaliana. BbrizStil shows similarity to a putative stress-induced protein from rice (Os02g0644100), with e-value of $1 e^{-54}$, and also with a putative stress-induced protein from $A$. thaliana (AT4G12400) with e-value of $1 e^{-47}$. Interpro analysis (Mulder et al. 2003) showed the presence of two conserved domains: STI1 domain that interacts with heat shock proteins and TPR1 domain (D'Andrea and Regan 2003), related to protein-protein interaction.

The full length BbrizHelic was obtained also by $5^{\prime}$ RACE. It consists of a fragment of $1,154 \mathrm{bp}$, with high similarity to the helicase-like protein from rice (Os01g0838 100). According to CDD bank analysis (Marchler-Bauer et al. 2002), BbrizHelic presented a RPA2_OBF familylike domain, characterized by having a DNA binding site. Members of this family are also associated with DNA replication, recombination and repair (Knoll and Puchta 2011).

The expression profile for BbrizStil (Fig. 6) and BbrizHelic (Fig. 7) was analyzed by ISH in the course of ovary development of apomictic and sexual $B$. brizantha. 
Table 1 Expressed sequence tags with differential expression determined by macroarray analysis in ovaries of sexual and apomictic Brachiaria brizantha plants

\begin{tabular}{|c|c|c|c|}
\hline EST & e value ID & Description accession number genebank & $\begin{array}{l}\text { Expression level } \\
\text { (sexual related } \\
\text { to apomictic) }\end{array}$ \\
\hline BbrizDMC1 B030IeII_002B09 & $3 e^{-99} 185 / 187(98 \%)$ & $\begin{array}{l}\text { DMC1 like protein-Oryza sativa (indica cultivar-group) } \\
\text { JG437131 }\end{array}$ & Repressed \\
\hline BbrizEF2 B030IeII_008E11 & $e^{-113} 201 / 209(96 \%)$ & $\begin{array}{l}\text { Elongation factor 2-Oryza sativa (japonica cultivar-group) } \\
\text { JG436816 }\end{array}$ & Repressed \\
\hline BbrizERD B030IeII_005E11 & $8 e^{-11} 52 / 138(37 \%)$ & Drought Stress Response Protein type ERD JK145790 & Repressed \\
\hline BbrizHelic B030IeII_007B07 & $4 e^{-25} 55 / 115(47 \%)$ & $\begin{array}{l}\text { Helicase like-Oryza sativa (japonica cultivar-group) } \\
\text { JG437003 }\end{array}$ & Repressed \\
\hline BbrizHyp B030IeII_002B08 & $6 e^{-06} 25 / 55(45 \%)$ & $\begin{array}{l}\text { Hypothetical protein-Oryza sativa (japonica cultivar-group) } \\
\text { JG437130 }\end{array}$ & Repressed \\
\hline BbrizMMF B030IeII_003F09 & $e^{-103} 189 / 221(85 \%)$ & $\begin{array}{l}\text { Mini Chromosome Maintenance Factor-Triticum aestivum } \\
\text { JG437216 }\end{array}$ & Repressed \\
\hline BbrizNup B030IeII_007F07 & $2 e^{-47} 89 / 113(78 \%)$ & Nucleoporin—Hyacinthus orientalis JG437436 & Repressed \\
\hline BbrizRan B030IeII_003H02 & $1 e^{-31} 67 / 68(98 \%)$ & Ran related to GTP_Zea mays JG437228 & Repressed \\
\hline BbrizSec13 B030IeII010H12 & $3 e^{-26} 53 / 59(89 \%)$ & $\begin{array}{l}\text { Sec13 type protein-Oryza sativa (japonica cultivar-group) } \\
\text { JG437606 }\end{array}$ & Repressed \\
\hline BbrizSti1 B030IeII_002C02 & $8 e^{-55} 104 / 116(89 \%)$ & $\begin{array}{l}\text { Stress induced protein, Sti1_-Oryza sativa } \\
\text { (japonica cultivar-group) JG437135 }\end{array}$ & Repressed \\
\hline BbrizTom1 B030IeII_005F07 & $1 e^{-70} 157 / 311(50 \%)$ & $\begin{array}{l}\text { Putative protein TOM1-Oryza sativa } \\
\text { (japonica cultivar-group) JG437318 }\end{array}$ & Repressed \\
\hline
\end{tabular}
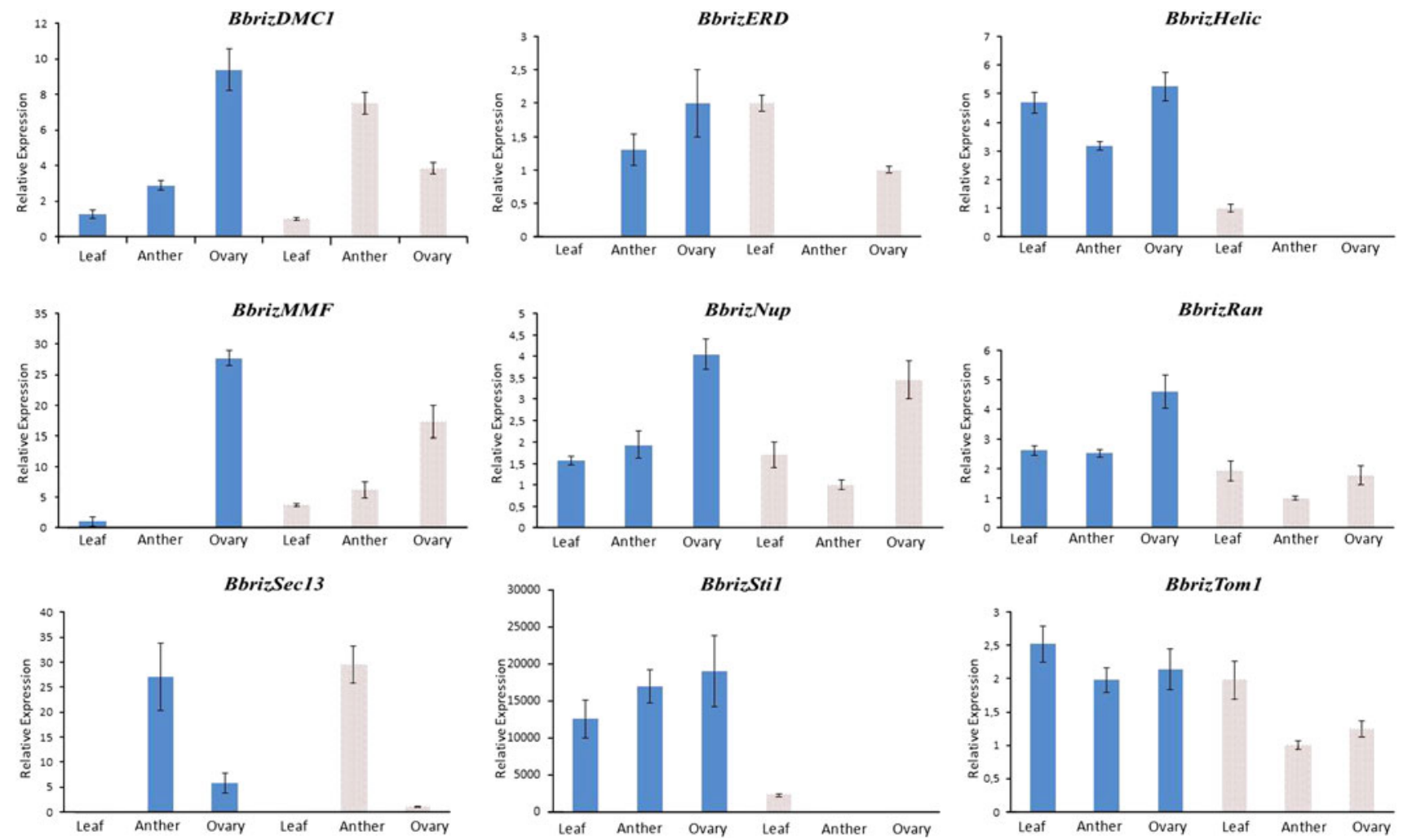

Fig. 4 Relative expression of nine genes in anthers, leaves and ovaries of apomictic (dark bars) and sexual (hatched bars) Brachiaria brizantha. Results represent the mean of three technical replicates of each sample. BbrizUBI was used as reference gene (Silveira et al. 2009). Bar $2 \times$ SEM (standard error of the mean) 

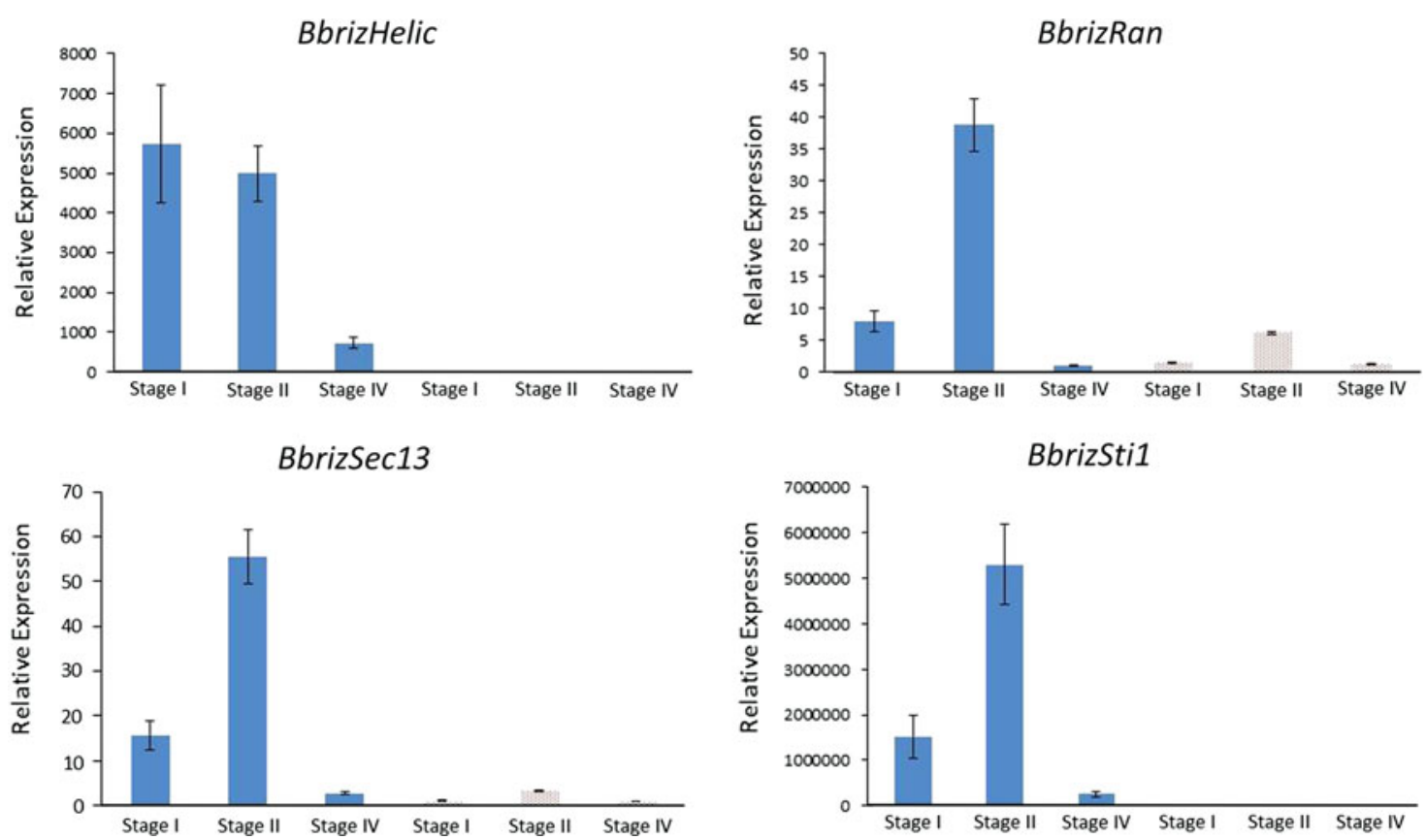

Fig. 5 Relative expression of four genes in ovaries of apomictic (dark bars) and sexual (hatched bars) Brachiaria brizantha at stages I and II of megasporogenesis and IV of megagametogenesis corresponding to mature embryo sac, according to Araujo et al. (2000).

Acridine orange staining was done to assess proper preservation of RNA in tissue sections. To certify that the signal observed in ISH was not due to probe crosshybridization, we performed the hybridization step using temperature of 42,55 and $60^{\circ} \mathrm{C}$. Antisense probes of BbrizStil and BbrizHelic were detected in ovaries from megasporogenesis to late megagametogenesis (stages I-IV), in apomictic B. brizantha. In the most stringent hybridization condition $\left(60^{\circ} \mathrm{C}\right)$, the signal was detected mostly in apomictic ovaries in megasporogenesis, corroborating RT-qPCR data. For BbrizStil, at early stages of apomictic development, the hybridization signal was detected in all cells of the ovule but with higher intensity in the megaspore mother cell when compared to the surrounding nucellar cells (Fig. 6a). A stronger signal was detected in surrounding nucellar cells rather than in the ais during differentiation (Fig. 6b). At megagametogenesis, when the embryo sac is already formed, a signal was detected in integuments and nucellar cells, with a weak signal in synergids, central cell and egg cell of the embryo sac (Fig. 6c). At later stages, when the embryo is already formed, no transcript was detected with the antisense probe. No hybridization was observed with the sense probe at any stage of development (Fig. 6d).

In apomictic $B$. brizantha, ISH signal detection of BbrizHelic was similar to BbrizStil. At stage I, the early stage of development, transcripts were detected in all the cells of the ovule, including megaspore mother cell and

Results represent the mean of three technical replicates of each sample. BbrizUBI was used as reference gene (Silveira et al. 2009). Bar $2 \times$ SEM (standard error of the mean)

nucellar cells with a weaker signal in the integuments that are at the beginning of their formation (Fig. 7a). At later stages, although there was a slighter lower detection of the probe, it was possible to observe a signal in some cells of the nucellus (Fig. 7b). Sections hybridized with the sense probe did not show any signal (Fig. 7c). At stage IV, in the mature embryo sac, a signal was detected in nucellar cells but not in the inner and outer integuments. The synergids had some signal of hybridization (Fig. 7d). At this same stage, in an ovule with a larger embryo sac, a hybridization signal was weaker in the cells of the embryo sac when compared to the surrounding nucellar cells (Fig. 7e).

\section{Discussion}

The characterization of ESTs from ovaries of apomictic plants will contribute to a better understanding of the differences between sexual and apomictic reproduction pathways. Nonetheless, analyses of ovaries, where these differences occur, are very complex. This is especially true of grasses, due to their reduced size, presence of only one ovary per flower and the difficulty of access and isolation. To date, a few sequenced libraries of megagametophytes of apomicts are available (Albertini et al. 2004; Calderini et al. 2006). This paper shows for the first time the construction and analysis of EST libraries from ovaries of B. brizantha. The ESTs analysis combined with 

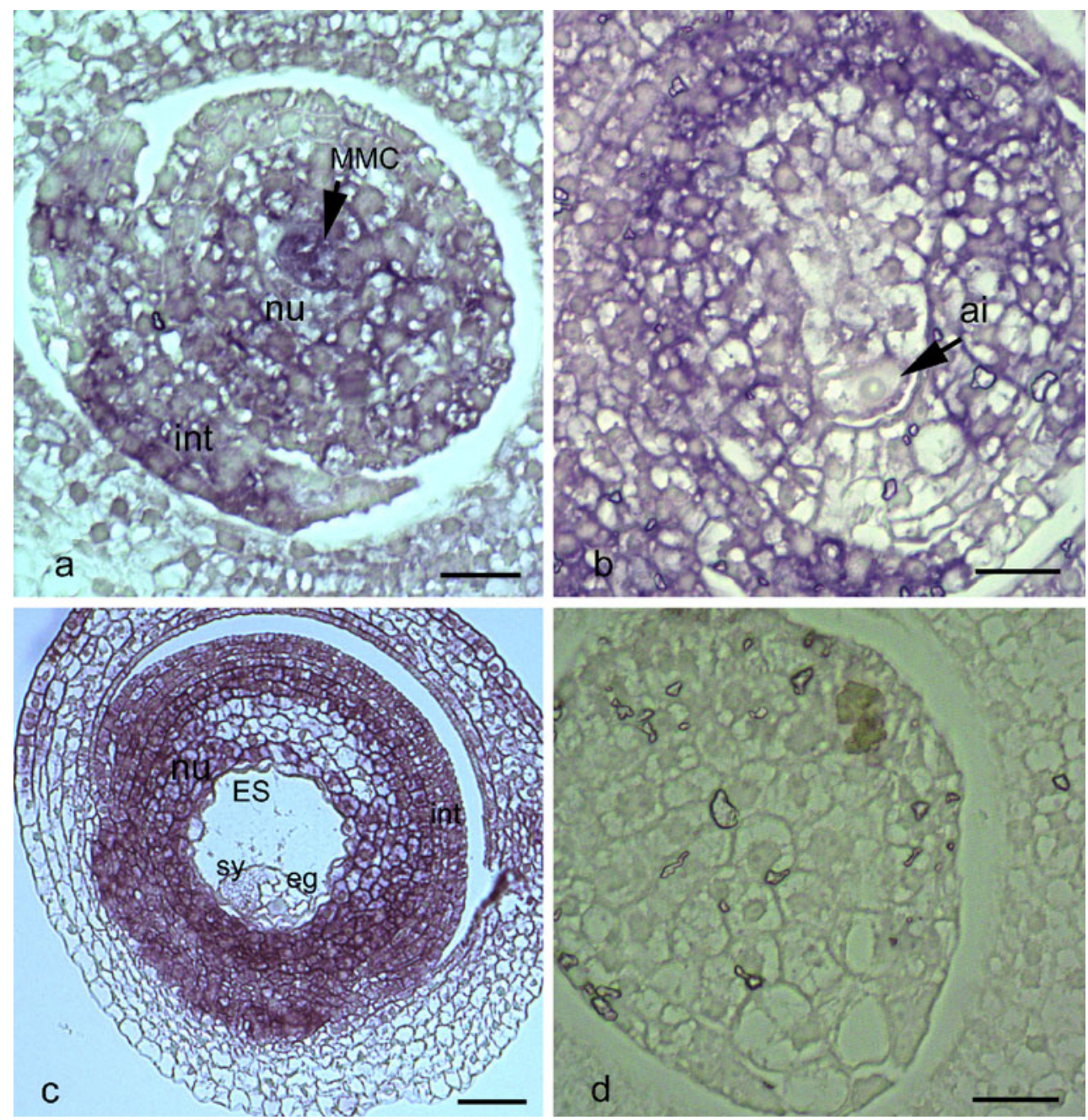

Fig. 6 In situ hybridization for BbrizStil in ovaries from apomictic Brachiaria brizantha using antisense (a-c) and sense (d) probes: a ovary showing labeling in nucellus and integuments, and mostly in megaspore mother cell, b ovary showing no signal in aposporous initial, c ovary with mature embryo sac, showing high signal in

macroarray, RT-qPCR and ISH analyses provide valuable information for those interested in apomixis.

Most of the ESTs described in this work came from ovaries of apomictic $B$. brizantha at megasporogenesis, the point in time at which megaspores degenerate and ai differentiate. The high quality of the libraries produced from ovaries was demonstrated and a higher number of $B$. brizantha ESTs showed similarity to the $S$. bicolor genome when compared to $B$. distachyon genome. This result is in accordance with phylogenetic data, since Brachiaria and Sorghum belong to the same Panicoideae subfamily, while Brachypodium belongs to the Pooideae subfamily. In addition, Sorghum shows species with a $2 \mathrm{n}$ aposporic-type embryo sac (Hanna et al. 1970; Carman et al. 2011), similarly to Brachiaria, and common genes could be involved in this same aposporic process. integuments and nucellus and lower signal in egg cell and synergids, d ovary hybridized with sense probe showing no signal. Bar $20 \mu \mathrm{m}$. ai aposporous initial, eg egg cell, ES mature embryo sac, int integuments, $M M C$ megaspore mother cell, $n u$ nucellus, sy synergids

The $B$. brizantha differential sequences previously described by Rodrigues et al. (2003) were not represented in the EST libraries (data not shown). Interestingly, most of the ESTs showed no hit to sequences already described in public databases. In addition, the two contigs with the highest number of reads are similar to a hypothetical protein and a no-hit sequence, pointing to the potential for novelty in gene discovery in these libraries. These results are in agreement with the data from Paspalum simplex (Polegri et al. 2010), in which most apomictic sequences also showed no hits to known sequences from public databases. The distribution into different functional categories on KOG suggests that the library obtained from the combination of four libraries of ovaries before anthesis is representative of the $B$. brizantha transcriptome complexity. The two categories that had the most abundant 


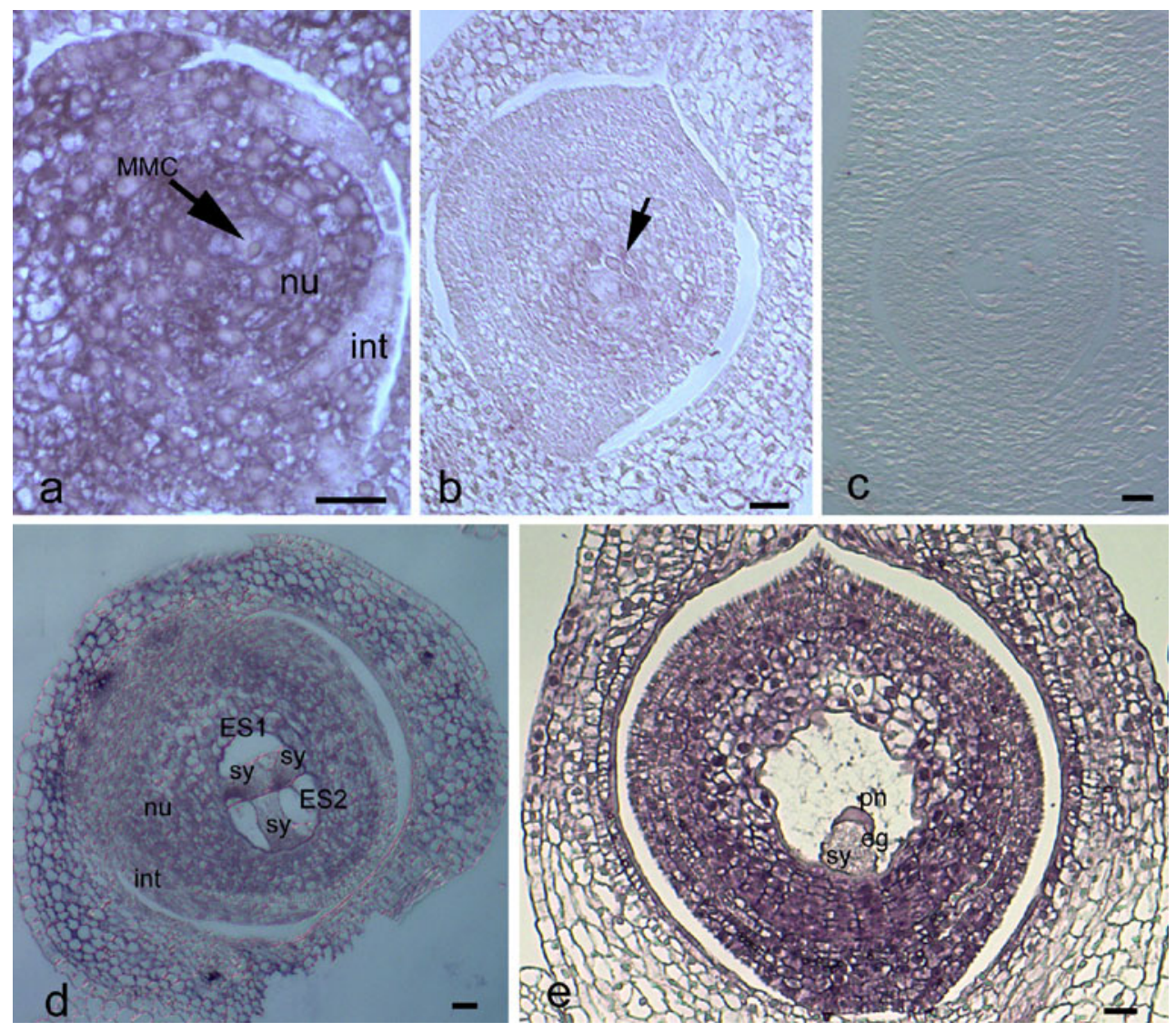

Fig. 7 In situ hybridization for BbrizHelic in ovaries from apomictic Brachiaria brizantha using antisense $(\mathbf{a}, \mathbf{b}, \mathbf{d}, \mathbf{e})$ and sense (c) probes: a showing labeling in nucellus, and megaspore mother cell, $\mathbf{b}$ showing stronger signal in some cells of the nucellus (arrow), c ovary showing no signal, d multiple mature embryo sacs showing signals at

transcripts were proteins related to posttranslational modification, protein turnover and chaperones, and the group of proteins with general function prediction only.

The differential expression of the ESTs with potential interest for the study of apomixis was first validated by macroarray and also by RT-qPCR and ISH. The lack of signal from $38 \%$ of the macroarray probes could be due to the low expression level or tissue/cell specificity of the genes chosen. Similar levels of elements that could not be evaluated were found with ovaries of Pennisetum ciliare (Singh et al. 2007). From the 11 ESTs with higher expression in apomictic $B$. brizantha, one showed similarity to sequences involved in meiosis (BbrizDMCl), two in cell cycle regulation (BbrizMMF; BbrizRan), and two in stress response (BbrizERD and BbrizStil). Nine out of 11: BbrizDMC1; BbrizERD; BbrizHelic; BbrizMMF; BbrizNup; BbrizRan; BbrizSec13; BbrizStil and BbrizToml were confirmed by RT-qPCR as being more expressed in apomictic ovaries than in sexual ones. Most of them showed higher expression in reproductive (anthers and ovaries) than in vegetative organs (leaves). Staged RT-qPCR for synergids and at nucellus, e mature embryo sac showing strong signal nucellar cells and weaker signal in the synergids, egg cell and in the central cell, near the polar nucleus. Bar $20 \mu \mathrm{m}$. eg egg cell, ES mature embryo sac, int integuments, $M M C$ megaspore mother cell, $n u$ nucellus, $p n$ polar nucleus, sy synergids

BbrizHelic; BbrizRan; BbrizSecl3 and BbrizStil showed a higher expression level in apomictic ovaries at megasporogenesis than at mature stage. In addition, the lower level of expression in sexuals, comparing to the apomicts was confirmed. Even though, the expression of these sequences was not ovary specific, the difference between their expression in sexual and apomictic ovaries in the early stages of ovary development, when the main events of differentiation between sexual and apomictic plants occur (Dusi and Willemse 1999; Araujo et al. 2000), suggest their involvement in the female reproductive development of apomictic $B$. brizantha. It is also important to mention that genes, including crucial regulators such as CAPRICE and TRIPTYCHON, may have conspicuous gene expression and have their tissue specific function triggered by the organ specific partners (Schellmann et al. 2002). The putative role of these ESTs during apomictic development is discussed below.

Regarding the putative role of Helicase, this sequence has a DNA binding domain, and members of this family are associated with genetic recombination (Mulder et al. 2003). 
Rodrigues et al. (2003) have also described a sequence involved in recombination (clone 20) which is preferentially expressed in ovaries of apomictic $B$. brizantha. The level of expression of BbrizHelic in the first stages of ovary development was higher in apomicts than in sexual plants, and this result points to an involvement at the beginning of ai differentiation of apomictic $B$. brizantha, in addition to the megasporogenesis events. In fact, ISH showed higher expression of BbrizHelic in nucellar cells positioned in the very region where ais usually differentiate in ovaries of apomictic Brachiaria plants (Dusi and Willemse 1999; Araujo et al. 2000).

The high expression of BbrizSec13 and BbrizRan in ovaries of apomictic plants, and more precisely, in ovaries during ais differentiation, could be due to their involvement in the transport of proteins related to specification of the nucellar cells that will form the megagametophyte of apomicts, possibly through an auxin pathway. Alterations in the patterns of auxin transport and synthesis caused identity changes in the constituent cells of the megagametophyte of A. thaliana (Pagnussat et al. 2009). Although there is a direct influence of auxin gradient on the formation of the mature embryo sac and its constituent cells, it is possible that this gradient results from a response to an unknown factor that leads to a cascade of cell differentiation (Pagnussat et al. 2009). RAN1 in Triticum aestivum participates in auxin signal pathway and its involvement in auxin response pathways and cell division has been suggested; it also has an important role during transport of proteins involved with mitosis and cell cycle (Wang and Liu 2006).

Among the nine Brachiaria ESTs with differential expression in ovaries of apomictic compared to sexual plants, two are related to stress response, BbrizERD and, notably, BbrizSti1. Stress-related genes have already been reported to be associated with apomictic development in other species. In Boechera spp., gene expression studies between diplosporic apomictic and sexual ovaries at different developmental stages have shown higher expression of stress-related sequences on apomictic ovaries from the stage of early megaspore mother cell formation to fertilized ovules (Sharbel et al. 2010). Also, the ASG1 (apomixis specific gene) from $P$. maximum, preferentially expressed in ovules of apomicts, presented similarity to proteins associated with drought stress, such as the protein RD22 from A. thaliana (Chen et al. 2005). The detection of BbrizStil in the megaspore mother cell, and in nucellar cells previously to ai differentiation leads to speculation on the involvement of stress-responsive genes in the induction of ai from somatic cells of the nucellus. Stress can trigger in vitro developmental processes such as somatic embryogenesis (Ikeda-Iwai et al. 2003; Kikuchi et al. 2006; Kumria et al. 2003). In the development of ais as well as in the development of somatic embryos, somatic cells are reorganized and enter a different pathway, changing their cell fate. In somatic embryogenesis, embryos are formed, while in aposporic apomixis unreduced embryo sacs are formed. Both developmental pathways were previously associated, as was the expression of the somatic embryogenesis receptor-like kinase (SERK) gene, involved in the fate of cells towards embryogenesis, which could also participate in the specification of ais in apomicts (Albertini et al. 2005). The mechanism of signal transduction of these phenomena could be similar and comprise auxin and stressinduced genes.

This work reports the first analysis of EST libraries of Brachiaria genus. The EST database produced revealed transcripts of Brachiaria ovaries especially valuable to identify genes associated to reproduction. It has also proved to be of great value in identifying genes expressed in apomicts as was done by macroarray and RT-qPCR. Among the sequences studied at the present work, BbrizHelic, BbrizRan, BbrizSEC13 and BbrizStil are especially interesting due to their putative involvement in megasporogenesis of apomicts. Further analysis of two sequences, BbrizStil and BbrizHelic, showed transcripts localized in nucellar tissues of ovaries of apomictic plants at stages of development previous to ai differentiation, suggesting their involvement on apomixis. The functional characterization of these genes will contribute to new insights on the megagametophyte development of apomicts.

Acknowledgments The authors gratefully acknowledge Samara Kalaoun, from UFRJ, for help with RT-qPCR experiments; Dr. Milton Moraes, from Fiocruz, for support material and equipment for RT-qPCR. From Embrapa, they thank Rafael W. de Souza, for dissecting ovaries; Dr. Luiz JCB. Carvalho and Dr. Marco V. Agostin for technical support and analyses of macroarray experiments; and Dr Julio CM. Rodrigues for comments on the manuscript. This work is part of EDS' $\mathrm{PhD}$ thesis from Pós-Graduação em Biotecnologia Vegetal, UFRJ, Brazil, with a partial fellowship from CAPES, CNPq and Embrapa. This work was partially supported by CNPq (478356/ 2006-4 - VTCC), Embrapa (02.05.1.02.00- VTCC) and Fundação de Amparo à Pesquisa do Rio de Janeiro (FAPERJ; E-26/102.861/2008 MA-F).

\section{References}

Albertini E, Marconi G, Barcaccia G, Raggi L, Falcinelli M (2004) Isolation of candidate genes for apomixis in Poa pratensis L. Plant Mol Biol 56:879-894

Albertini E, Marconi G, Reale L, Barcaccia G, Porceddu A, Ferratini F, Falcinelli M (2005) SERK and APOSTART. Candidate genes for apomixis in Poa pratensis. Plant Physiol 138:2185-2199

Altschul SF, Madden TL, Schaffer AA, Zhang J, Zhang J, Zhang Z, Miller W, Lipman DJ (1997) Gapped BLAST and PSI-BLAST: a new generation of protein database search programs. Nucl Acid Res 25:3389-3402

Alves ER, Carneiro VTC, Araujo ACG (2001) Direct evidence of pseudogamy in an apomictic Brachiaria brizantha (Poaceae). Sexual Plant Reprod 14(4):207-212 
Alves ER, Carneiro VTC, Dusi DMA (2007) In situ localization of three cDNA sequences associated with the later stages of aposporic embryo sac development of Brachiaria brizantha. Protoplasma 231(3-4):161-171

Araujo ACG, Mukhambetzhanov S, Pozzobon MT, Santana EF, Carneiro VTC (2000) Female gametophyte development in apomictic and sexual Brachiaria brizantha (Poaceae). Rév Cytol Biol Végétales-Le Botaniste Tome 23(1-2):13-28

Araujo ACG, Nóbrega JM, Pozzobon MT, Carneiro VTC (2005) Evidence of sexuality in induced tetraploids of Brachiaria brizantha (Poaceae) Euphytica 144:39-50

Araújo SAC, Deminics BB, Campos PRSS (2008) Melhoramento Genético de Plantas Forrageiras Tropicais no Brasil. Arch Zootec 57(R):61-76

Ashburner M, Ball CA, Blake JA, Botstein D, Butler H, Cherry JM, Davis AP, Dolinski K, Dwight SS, Eppig JT, Harris MA, Hill DP, Issel-Tarver L, Kasarskis A, Lewis S, Matese JC, Richardson JE, Ringwald M, Rubin GM, Sherlock G (2000) Gene ontology: tool for the unification of biology. The Gene Ontology Consortium. Nat Genet 25(1):25-29

Benson DA, Karsch-Mizrachi I, Lipman DJ, Ostel J, Wheeler DL (2008) GenBank. Nucl Acids Res 36:D25-D30

Calderini O, Chang S, de Jong H, Busti A, Paolocci F, Arcioni S, de Vries S, Abma-Henkens M, Lankhorst R, Donnison I, Pupilli F (2006) Molecular cytogenetics and DNA sequence analysis of an apomixis-linked BAC in Paspalum simplex reveal a non pericentromere location and partial microcolinearity with rice. Theor Appl Genet 112(6):1179-1191. doi:10.1007/s00122-0060220-7

Carman J, Jamison M, Elliott E, Dwivedi K, Naumova T (2011) Apospory appears to accelerate onset of meiosis and sexual embryo sac formation in sorghum ovules. BMC Plant Biol 11(1):9

Cervigni G, Paniego N, Pessino S, Selva J, Díaz M, Spangenberg G, Echenique V (2008) Gene expression in diplosporous and sexual Eragrostis curvula; genotypes with differing ploidy levels. Plant Mol Biol 67(1):11-23. doi:10.1007/s11103-008-9305-9

Chaudurhy AM, Ming L, Miller C, Craig S, Dennis ES, Peacock WJ (1997) Fertilization-independent seed development in Arabidopsis thaliana. Proc Natl Acad Sci USA 94:4223-4228

Chen L, Guan L, Seo M, Hoffmann F, Adachi T (2005) Developmental expression of ASG-1 during gametogenesis in apomictic guinea grass (Panicum maximum). J Plant Physiol 162(10): $1141-1148$

CREMAQ P (2010) The miracle of the cerrado. Brazil has revolutionised its own farms. Can it do the same for others? The Economist. http://www.economist.com/node/16886442/ print?story_id=16886442

Chu H-H, Holmes MH (2001) DNA sequence quality trimming and vector removal. Bioinformatics 17:1093-1104

D'Andrea LD, Regan L (2003) TPR proteins: the versatile helix. Trends Biochem Sci 28(12):655-662. doi:10.1016/j.tibs.2003. 10.007

d'Erfurth I, Jolivet S, Froger N, Catrice O, Novatchkova M, Mercier $\mathrm{R}$ (2009) Turning meiosis into mitosis. PLoS Biol 7(6): e1000124

Dusi DMA (2001) Apomixis in Brachiaria decumbens Stapf. PhD thesis, University of Wageningen, Wageningen

Dusi DMA, Willemse MTM (1999) Apomixis in Brachiaria decumbens Stapf.: gametophytic development and reproductive calendar. Acta Biol Cracov Bot 41:151-162

Ewing B, Hillier L, Wendl MC, Green P (1998) Base calling of automated sequence traces using phred. Genome Res 8:175-185

Gasteiger E, Jung E, Bairoch A (2001) SWISS-PROT: connecting biomolecular knowledge via a protein database. Curr Issues Mol Biol 3(3):47-55
Grossniklaus U (2001) From sexuality to apomixis: molecular and genetic approaches. In: Savidan Y, Carman JG, Dresselhaus T (eds) The flowering of apomixis: from mechanisms to genetic engineering. CIMMYT, IRD, European Commission DG VI (FAIR), Mexico, DF, pp 168-211

Hanna WW, Schertz KF, Bashaw EC (1970) Apospory in Sorghum bicolor (L.) Moench. Science 170:338-339

Huanca-Mamani W, Garcia-Aguilar M, Leon-Martinez G, Grossniklaus U, Vielle-Calzada J-P (2005) CHR11, a chromatin-remodeling factor essential for nuclear proliferation during female gametogenesis in Arabidopsis thaliana. Proc Natl Acad Sci USA 102(47):17231-17236

Huang X, Madan A (1998) cap3: a DNA sequence assembly program. Genome Res 9:868-877

Hulsen T, Huynen MA, Vlieg J, Groenen PMA (2006) Benchmarking ortholog identification methods using functional genomics data. Genome Biol 7:R31

Ikeda-Iwai M, Umehara M, Satoh S, Kamada H (2003) Stress-induced somatic embryogenesis in vegetative tissues of Arabidopsis thaliana. Plant J 34(1):107-114

Kikuchi A, Sanuki N, Higashi K, Koshiba T, Kamada H (2006) Abscisic acid and stress treatment are essential for the acquisition of embryogenic competence by carrot somatic cells. Planta 223(4):637-645

Knoll A, Puchta H (2011) The role of DNA helicases and their interaction partners in genome stability and meiotic recombination in plants. J Exp Bot 62(5):1565-1579

Kumria R, Sunnichan VG, Das DK, Gupta SK, Reddy VS, Bhatnagar RK, Leelavathi S (2003) High-frequency somatic embryo production and maturation into normal plants in cotton (Gossypium hirsutum) through metabolic stress. Plant Cell Rep 21(7):635-639

Marchler-Bauer A, Panchenko AR, Shoemaker BA, Thiessen PA LYG, Bryant SH (2002) CDD: a database of conserved domain alignments with links to domain three-dimensional structure. Nucl Acids Res 30(1):281-283

Marimuthu MPA, Jolivet S, Ravi M, Pereira L, Davda JN, Cromer L, Wang L, Nogué F, Chan SWL, Siddiqi I, Mercier R (2011) Synthetic clonal reproduction through seeds. Science 331(6019): 876. doi:10.1126/science. 1199682

Miles JW, Maass BL, CBd Valle (1996) Brachiaria: biology, agronomy and improvement, vol 1, 1st edn. CIAT, Cali

Mulder NJ, Apweiler R, Attwood TK, Bairoch A, Barrell D, Bateman A, Binns D, Biswas M, Bradley P, Bork P, Bucher P, Copley RR, Courcelle E, Das U, Durbin R, Falquet L, Fleischmann W, Griffiths-Jones S, Haft D, Harte N, Hulo N, Kahn D, Kanapin A, Krestyaninova M, Lopez R, Letunic I, Lonsdale D, Silventoinen V, Orchard SE, Pagni M, Peyruc D, Ponting CP, Selengut JD, Servant F, Sigrist CJA, Vaughan R, Zdobnov EM (2003) The InterPro Database, 2003 brings increased coverage and new features. Nucl Acids Res 31:315-318

Ngendahayo M (1988) Méchanismes de la reproduction dans le genre Brachiaria. Doctor thesis, Université Catholique de Louvain, Louvain, Belgium

Nogler GA (1984) Genetics of apospory in apomictic Ranunculus auricomus V. Conclusions Bot Helv 94:411-422

Nogler GA (1994) Genetics of gametophytic apomixis-a historical sketch. Pol Bot Stud 8:5-11

Nogueira FTS, De Rosa VEJ, Menossi M, Ulian EC, Arruda P (2003) RNA expression profiles and data mining of sugarcane response to low temperature. Plant Physiol 132:1811-1824

Ohad N, Marossian L, Hsu YC, Williams C, Repetti P, Fisher RL (1996) A mutation that allows endosperm development without fertilization. Proc Natl Acad Sci USA 93:5319-5324

Olmedo-Monfil V, Duran-Figueroa N, Arteaga-Vazquez M, DemesaArevalo E, Autran D, Grimanelli D, Slotkin RK, Martienssen 
RA, Vielle-Calzada J-P (2010) Control of female gamete formation by a small RNA pathway in Arabidopsis. Nature 464(7288):628-632

Ozias-Akins P (2006) Apomixis: developmental characteristics and genetics. Crit Rev Plant Sci 25:199-214

Pagnussat GC, Alandete-Saez M, Bowman JL, Sundaresan V (2009) Auxin-dependent patterning and gamete specification in the Arabidopsis female gametophyte. Science 324(5935):1684-1689. doi:10.1126/science.1167324

Pappas GJ, Miranda RP, Martins NF, Togawa RC, Costa MC (2008) SisGen: a CORBA- Based data management program for DNA sequencing projects. Lect Notes Comput Sci 5109:116-123

Pertea G, Huang X, Liang F, Antonescu V, Sultana R, Karamycheva S, Lee Y, White J, Cheung J, Parvizi B, Tsai J, Quackenbush J (2003) TIGR Gene Indices clustering tools (TGICL): a software system for fast clustering of large EST datasets. Bioinformatics (Oxford, England) 19(5):651-652

Pinheiro AA, Pozzobon MT, do Valle CB, Penteado MIO, Carneiro VTC (2000) Duplication of the chromosome number of diploid Brachiaria brizantha plants using colchicine. Plant Cell Rep 19(3):274-278

Polegri L, Calderini O, Arcioni S, Pupilli F (2010) Specific expression of apomixis-linked alleles revealed by comparative transcriptomic analysis of sexual and apomictic Paspalum simplex Morong flowers. J Exp Bot 61(6):1869-1883. doi:10.1093/ jxb/erq054

Proite K, Leal-Bertioli S, Bertioli D, Moretzsohn M, da Silva F, Martins N, Guimaraes P (2007) ESTs from a wild Arachis species for gene discovery and marker development. BMC Plant Biol 7(1):7

Ravi M, Marimuthu MPA, Siddiqi I (2008) Gamete formation without meiosis in Arabidopsis. Nature 451:1121-1125

Rodrigues JCM, Cabral GB, Dusi DMA, Mello LV, Rigden D, Carneiro VTC (2003) Identification of differentially expressed cDNA sequences in ovaries of sexual and apomictic plants of Brachiaria brizantha. Plant Mol Biol 53:745-757

Sambrook J, Fritsch EF, Maniatis T (1989) Molecular cloning a laboratory manual, vol 1. Cold Spring Harbor Laboratory Press, New York

Schoof H, Ernst R, Nazarov V, Pfeifer L, Mewes HW, Mayer KFX (2004) MIPS Arabidopsis thaliana Database (MAtDB): an integrated biological knowledge resource for plant genomics. Nucl Acids Res 32(suppl 1):D373-D376. doi:10.1093/nar/ gkh068
Sharbel TF, Voigt M-L, Corral JM, Galla G, Kumlehn J, Klukas C, Schreiber F, Vogel H, Rotter B (2010) Apomictic and sexual ovules of Boechera display heterochronic global gene expression patterns. Plant Cell 22(3):655-671. doi:10.1105/tpc.109.072223

Schellmann S, Schnittger A, Kirik V, Wada T, Okada K, Beermann A, Thumfahrt J, Jurgens G, Hulskamp M (2002) TRIPTYCHON and CAPRICE mediate lateral inhibition during trichome and root hair patterning in Arabidopsis. EMBO J 21(19):5036-5046

Silveira ED, Alves-Ferreira M, Guimarães LA, Silva FR, Carneiro VTC (2009) Selection of reference genes for quantitative real time PCR expression studies in the apomictic and sexual grass Brachiaria brizantha. BMC Plant Biol 9:84

Singh M, Burson B, Finlayson S (2007) Isolation of candidate genes for apomictic development in buffelgrass (Pennisetum ciliare). Plant Mol Biol 64(6):673-682. doi:10.1007/s11103-007-9188-1

Singh M, Goel S, Meeley R, Dantec C, Parrinello H, Michaud C, Leblanc O, Grimanelli D (2011) Production of viable gametes without meiosis in maize deficient for an ARGONAUTE protein. Plant Cell. doi:10.1105/tpc.110.079020

Spillane C, Curtis MD, Grossniklaus U (2004) Apomixis technology development-virgin births in farmers' fields? Nat Biotechnol 22(6):687-691

Tatusov RL, Fedorova ND, Jackson JD, Jacobs AR, Kiryutin B, Koonin EV, Krylov DM, Mazumder R, Mekhedov SL, Nikolskaya AN, Rao BS, Smirnov S, Sverdlov AV, Vasudevan S, Wolf YI, Yin JJ, Natale DA (2003) The COG database: an updated version includes eukaryotes. BMC Bioinf 4:41

Telles GP, FRd Silva (2001) Trimming and clustering sugarcane ESTs. Genet Mol Biol 24:1-4. doi:10.1590/S1415-4757200100 0100004

Tucker MR, Araujo ACG, Paech N, Hecht V, Schmidt EDL, Rossel J-B, De Vries SC, Koltunow AMG (2003) Sexual and apomictic reproduction in Hieracium subgenus Pilosella are closely interrelated developmental pathways. Plant Cell 15:1524-1537

Wang C, Liu Z (2006) Arabidopsis ribonucleotide reductases are critical for cell cycle progression, DNA damage repair, and plant development. Plant Cell 18(2):350-365. doi:10.1105/tpc.105. 037044

Yamada-Akiyama H, Akiyama Y, Ebina M, Xu Q, Tsuruta S-I, Yazaki J, Kishimoto N, Kikuchi S, Takahara M, Takamizo T, Sugita S-I, Nakagawa H (2009) Analysis of expressed sequence tags in apomictic guineagrass (Panicum maximum). J Plant Physiol 166(7):750-761 